GENERAL ARTICLE

\title{
Adaptation of agricultural crop production to climate change: A policy framework for Sri Lanka
}

\author{
W.A.J.M. De Costa \\ Department of Crop Science, Faculty of Agriculture, University of Peradeniya, Peradeniya.
}

Revised: 23 October 2009 ; Accepted: 21 December 2009

\begin{abstract}
Agriculture is one of the key sectors of the Sri Lankan economy, which contributes a significant percentage to its gross domestic product (GDP) and provides direct or indirect employment to a sizeable proportion of its population. Climate change involves long-term slow changes in climate, short-term year-to-year climatic variability and unpredictable extreme climatic events. Agriculture, especially crop production, is highly dependent on the prevailing weather conditions and therefore is highly sensitive to climate change, both short-term and long-term. Almost all General Circulation Models predict that the processes of climate change such as increasing atmospheric concentrations of greenhouse gases and global warming will continue well into the $21^{\text {st }}$ century even if the mitigation measures to minimize the causes of climate change exert maximum effect. Therefore, it is imperative that a well-co-ordinated and sustained effort is set in motion to increase the capacity of Sri Lankan agriculture to adapt to short and long-term climate change. Adaptation involves measures to minimize the impacts of climate change. At present, implementation of climate change adaptation measures in Sri Lanka is piecemeal and lacks co-ordination and direction. Hence, a clear policy framework identifying the measures to be pursued and the roles of different stakeholders is needed for allocating and channelling the necessary financial and human resources for successful adaptation to climate change. A clear and comprehensive policy framework also becomes the basis for development of an effective road map and an action plan to achieve successful adaptation. This paper discusses a policy framework for adaptation of Sri Lankan agriculture to climate change based on the following components: (a) Quantification and forecasting of climate change; (b) Assessment of impacts and vulnerability to climate change; (c) Identification and formulation of responses to adapt to climate change; (d) Creating and strengthening the institutional framework and infrastructure to implement and monitor adaptation measures to climate change. Major advances in scientific research on components a, b and c, both locally and internationally, are
\end{abstract}

briefly discussed and key policy measures to facilitate and accelerate their progress along with the relevant stakeholders are identified. Importance of allocating adequate resources to promote research on all aspects of climate change and their impacts by developing infrastructure, a critical mass of experts and an institutional framework to effectively link all stakeholders to channel the formulated adaptation measures to the farming communities at the grass-root level are emphasized.

Keywords: Adaptation, climate change impacts, policy, rice, tea, vulnerability

\section{INTRODUCTION}

\section{Role of agriculture in Sri Lanka}

Agriculture is one of the key sectors of the Sri Lankan economy, especially in view of the global food crisis $^{1}$ and the heightened awareness on ensuring national food security. In 2007, the agriculture sector contributed $11.9 \%$ to the national $\mathrm{GDP}^{2}$, while showing a $3.3 \%$ growth relative to 2006 . The sector provided direct employment to $31.3 \%$ of the total labour force in $2007^{2}$. Furthermore, it is estimated that the agriculture-related activities provide the major source of employment and livelihood for nearly $72 \%$ of the Sri Lankan population ${ }^{3}$. In a broad sense, agriculture includes crop production, animal husbandry and arguably, forestry and fisheries as well. In Sri Lanka, the contribution to the GDP from agriculture comes predominantly from crop production which accounted for $78 \%$ of the $11.9 \%$ contribution to the GDP from agriculture as a whole in $2007^{2}$. In comparison, the respective contributions from livestock, forestry and fisheries sectors were 7.6\%, 5.0\% and 9.2\% out of the $11.9 \%$. Therefore, at present, crop production

janendrad@yahoo.com

$\dagger$ Based on an oral presentation made by the author at the Symposium on Promoting Knowledge Transfer to Strengthening Disaster Risk Reduction and Climate Change Adaptation, 7-8 July 2009, Colombo. 
dominates the Sri Lankan agriculture. Among the specific crops, paddy, tea and coconut make up the three largest components of the $11.9 \%$ contribution from agriculture to the GDP with $13.4 \%, 10.1 \%$ and $10.9 \%$ respectively.

\section{Climate, climate change and climate variability}

Climate is the totality of above-ground environmental factors, which includes rainfall, air temperature, solar radiation, relative humidity, atmospheric composition and air circulation, and their long-term variation. The term 'Climate Change' strictly refers to a statistically significant and persistent shift in the long-term average of climate ${ }^{4}$. However, for a long-term shift in average climate to occur, short-term variations of a higher magnitude should occur. Therefore, a discussion on climate change and its implications automatically involves both its short-term variation (strictly termed 'Climate Variability') and long-term shifts. Extreme climatic events such as high intensity precipitation events, floods, droughts, heat waves, typhoons, cyclones and tornadoes form important components of the short-term climate variability. However, evidence is emerging that environmental processes leading to long-term climate change are likely to have contributed to an increasing frequency of extreme climatic events ${ }^{5,6}$.

\section{Climate change in Sri Lanka}

Although Sri Lanka has had a fairly well-established network of meteorological data collecting stations over a long period of time dating back to the second half of the $19^{\text {th }}$ century, there have been only a few in-depth analyses on climate change in Sri Lanka ${ }^{7-9}$. Statistically significant long-term increasing trends for annual mean air temperature and decreasing long-term trends in annual precipitation have been shown for several locations representing different agro-ecological zones of Sri Lanka ${ }^{7-9}$. Furthermore, long-term decreasing and increasing trends have been shown for the four principal rainfall seasons (i.e. south-west and north-east monsoons and the two inter-monsoons) for different locations in Sri Lanka ${ }^{10}$. Mean rainfall intensity (MRI) of the southwest monsoon season in Sri Lanka has shown significant spatial and temporal trends for different regions ${ }^{11}$. Variation of both MRI and amount of rainfall from different monsoon seasons has shown correlations with the occurrence of El-Niño Southern Oscillation (ENSO) events $^{9-11}$. There is evidence that ENSO-related shifts in rainfall may have changed with long-term climate change ${ }^{7}$. A previous study showed significant variation in the magnitudes of climate variability at different locations in Sri Lanka ${ }^{7}$.

\section{Impacts of climate on Sri Lankan agriculture}

Agriculture, especially crop production, is highly sensitive to both short and long-term changes in climate. The two principal crops of Sri Lankan agriculture, rice and tea, are both highly influenced by variations in temperature and rainfall ${ }^{12-14}$. Rice, being a crop grown with standing water for most of its life cycle, requires $1500-2000 \mathrm{~mm}$ of water per season, depending on the climate and soil characteristics ${ }^{15}$. Grain development of rice is highly sensitive to temperature during its reproductive stage, with significant increases in grain sterility occurring when temperature increases beyond $34{ }^{\circ} \mathrm{C}$ even for a few hours ${ }^{16}$. Increasing grain sterility has been reported from several rice-growing districts in the dry zone of Sri Lanka, especially during the warmer, minor rainfall season (locally known as the Yala season) during which temperatures are highly likely to exceed the upper threshold of $34{ }^{\circ} \mathrm{C}$. Weerakoon et al. ${ }^{17}$ showed that hightemperature-induced grain sterility in rice is exacerbated at high humidities. Like rice, tea also requires a welldistributed rainfall regime with a minimum of $200 \mathrm{~mm}$ per month ${ }^{18}$. The processes of initiation and expansion of young shoots of tea, which are harvested as yield, are also intimately linked to temperature ${ }^{19}$. In addition to the longterm shifts in rainfall and temperature regimes, extreme climatic events such as droughts and episodes of high temperature can cause substantial damage to both rice and tea crops. Such damage has serious repercussions on the national food security and foreign exchange earnings while causing substantial socio-economic damage to the large number of families that are dependent on these two crops. Similar adverse impacts are experienced by other crops (i.e. coarse-grained cereals, pulses, root and tuber crops, spice crops, fruits and vegetables etc.) $)^{20,21}$ and their stakeholders as well when confronted with events and phenomena of climate change.

\section{Adaptation to climate change and importance of a policy framework}

The high degree of sensitivity of the major agricultural crops in Sri Lanka to climate change, principally to increased temperature and decreased rainfall regimes and to extreme climatic events, means that both shortand long-term measures have to be adopted to minimize their adverse impacts. Mitigation and adaptation are the two principal pathways to minimize adverse impacts of climate change. Mitigation involves addressing the causes of climate change such as reducing anthropogenic emission of greenhouse gases, cleaner energy generation and reduced deforestation. However, even the most effective mitigation measures would not be able to completely reverse the atmospheric processes, which have been set in motion to cause climate change ${ }^{22,23}$. 
Therefore, while pursuing mitigation options, measures for adapting to the continuing changes in climate have to be pursued ${ }^{24}$. Previous studies ${ }^{25}$ define adaptation measures as actions that will reduce the impacts of climate change. Implementation of effective adaptation measures to climate change requires both leadership at the top administrative level and willingness to pursue those adaptation measures at the grass root level. Political will of the legislators and politically-driven administrators and sensitizing programmes for the rural populace of farmers on how their lifestyles stand to benefit by mitigation and adaptation are key factors in successful implementation of adaptation measures. Therefore, a clear policy framework identifying the measures to be pursued and the roles of different stakeholders is needed to link the policy formulators with all stakeholders and for allocating and channelling the necessary financial and human resources for successful adaptation to climate change. A clear and comprehensive policy framework also becomes the basis for development of an effective road map to achieve successful adaptation. The objective of this paper is to propose a broad outline of such a policy framework.

\section{Broad outline of a policy framework for adaptation of Sri Lankan agriculture to climate change}

A policy for adaptation to climate change should be based on the following:

(a) Quantification and forecasting of climate change

(b) Assessment of impacts and vulnerability to climate change

(c) Identification and formulation of responses to adapt to climate change

(d) Creating and strengthening the institutional framework and infrastructure to implement and monitor adaptation measures to climate change

Given below is a description of the key adaptation measures and personnel involved in each of the above components. While the four pathways listed above logically follow each other sequentially, in practice they can be undertaken concurrently with advances on each front leading to further development of others.

\section{Quantification and forecasting of climate change}

The key changes of climate that would influence agriculture at the global scale and their causative factors are already identified and well-documented ${ }^{26,27}$. These include increasing atmospheric $\mathrm{CO}_{2}^{4,26,27}$ and consequent warming of the lower atmosphere ${ }^{4,26}$, changes in precipitation patterns ${ }^{26}$, sea level rise $^{26}$ and increased frequency of extreme climatic events ${ }^{5,6}$. However, while the overall changes in climate and their probable magnitudes have been quantified to an acceptable degree of accuracy, their spatial variation across different parts of the earth are by no means fully quantified ${ }^{28,29}$. A small country like Sri Lanka is especially at a disadvantage in general circulation models (GCMs) and global climate models because of its smaller land mass in comparison to the minimum grid units of a GCM. Therefore, an in-depth analysis of long-term climate data at different locations of Sri Lanka is needed. This is especially so in view of the diverse agro-ecological zones in Sri Lanka, which are the result of its unique topography and the monsoon systems that bring its rainfall ${ }^{8,30-33}$. Although Sri Lanka has a welldistributed network of meteorological stations, most of them collect only the basic data such as daily rainfall and temperature. Hence, there is a need to upgrade the data gathering capability of the existing meteorological stations, for example by installation of additional automatic weather stations. The existing meteorological stations are not evenly distributed and do not cover all parts of the country. The northern and eastern provinces have only a few stations and the south-west and northwest regions also have only a few at widely-scattered locations. Hence, there is an urgent need to establish new meteorological stations in the above areas so that a complete picture of the Sri Lankan climate, its short-term variability and long-term change can be obtained.

Development of methodology to quantify and forecast climate change is as important as the data collection itself. While the methodology for quantifying long-term climate change is fairly well-established ${ }^{27,34}$, the methodology for quantifying the extreme climate events is still being developed ${ }^{35,36}$. In comparison to methodology for quantification of climate change, methodology for forecasting climate change and its spatial and temporal variation needs further research efforts by taking in to account the wide range of possibilities and by reducing the current uncertainties in predictions ${ }^{37-43}$.

The key personnel involved in quantification and forecasting climate change are the meteorologists and relavant research scientists such as statisticians, climate modelers, geographers and atmospheric scientists. Another important group of personnel are the technicians who install and maintain the meteorological stations and the ground level collectors of data.

\section{Assessment of impacts and vulnerability to climate change}

Quantification and prediction of climate change and its spatial and temporal variation should be followed by comprehensive assessments of their impacts 
on different aspects of agriculture. This involves a substantial investment of funds, infrastructure and manpower for research to quantify these impacts. Both crops and animal husbandry, which are the two principal branches of agriculture, are highly sensitive to the increases in temperature. Specifically, key crops in Sri Lankan agriculture, such as rice and tea, are influenced by increasing atmospheric $\mathrm{CO}_{2}$ concentrations $\left(\mathrm{C}_{\mathrm{a}}\right)$, increasing temperatures and changing rainfall and evapotranspiration regimes ${ }^{44-48}$. Increasing $\mathrm{C}_{\mathrm{a}}$ stimulates the growth of all plant species and increases the productivity of all agricultural crops by varying magnitudes depending on species and variety ${ }^{49-52}$. On the other hand, increasing temperatures will be beneficial for crops growing presently in cooler environments (i.e. tea at higher altitudes in Sri Lanka ${ }^{48,53}$ ) by increasing their growth and yield formation processes ${ }^{51,54}$. However, crops that are currently growing in intermediate and warmer environments (i.e. low-country wet and dry zones of Sri Lanka) will be adversely affected because higher temperatures and increased frequency of drought will damage their yield formation processes ${ }^{21,54-56}$. For example, a previous study ${ }^{57}$ showed that rice yields at the International Rice Research Institute (SRRI) in the Philippines decreased by $10 \%$ for each $1^{\circ} \mathrm{C}$ rise in minimum (i.e. night time) temperature during the dry season (i.e. January to April). Another study ${ }^{58}$ showed that increasing night temperatures will reduce the stimulatory effects of increasing $\mathrm{CO}_{2}$ on rice yields. Temperature increases will reduce the durations of most cereal crops by hastening their phenological development ${ }^{59}$. A previous study ${ }^{60}$ has also shown that short episodes of high temperatures can have significant adverse impacts on flowering and yield formation of crops, thus highlighting the importance of taking into account the impacts of short-term climate variability and extreme climatic events. There are conflicting reports on whether the stimulatory effects of increasing $\mathrm{CO}_{2}$ on crop yields could offset the negative effects of increasing temperatures ${ }^{61-64}$. Rice grown near coastal zones will be increasingly affected by increasing salinity arising from sea level rise and intrusion of sea water.

Short and long-term climate change also influences the incidence of pests and diseases of important agricultural crops. Anderson et $a l^{65}$ have identified anthropogenic climate change as one of the principal causes of emerging infectious diseases (EIDs) in crops and wild plants. Climate change could induce changes in plant disease incidence by modifying host-pathogen interactions ${ }^{66}$ through changes in the stages and rates of development of pathogens and changes in host plant resistance ${ }^{67}$. This could result in shifts in the geographical distribution of the pathogen and the incidence of the specific disease caused by it. For example, a previous study has shown that there have been marked shifts in the populations of different nematode species affecting tea crops in different elevation zones of Sri Lanka. Incidence of the nematode species Meloidogyne brevicauda, which requires an optimum soil temperature of $12^{\circ} \mathrm{C}$, has been observed to decrease in the higher elevations (i.e. $>1000 \mathrm{~m}$ above $\mathrm{msl}$ ), probably because of increasing soil temperatures. Interestingly, the incidence of another nematode species Pratylenchus loosi, which is adapted to warmer soil temperatures with the optimum range at $18^{\circ}-20^{\circ} \mathrm{C}$ has increased in tea lands on the upper elevations. Furthermore, naturally-occurring bacterial and fungal enemies of $M$. brevicauda were observed to increase with increasing soil temperatures. A recent study ${ }^{69}$ observed significant shifts in the naturallyoccurring microbial population on the phyllosphere (leaf surface) of rice crops growing in the field under elevated atmospheric $\mathrm{CO}_{2}$. While the diversity and density of the phyllosphere-inhabiting bacterial population increased at elevated $\mathrm{CO}_{2}$, the diversity and density of the fungal population decreased. The study also observed significant variation among different rice varieties in the above response. Shifts in the rainfall regime, either in terms of total annual rainfall or its distribution within the year or both, could induce shifts in important fungal diseases such as Oidium leaf fall in rubber, caused by Oidium hevea, and blister blight in tea caused by Exobasidium vexans. Proliferation of both these fungal pathogens is promoted by frequent intermittent rainfall, mist and high atmospheric humidity. Infection of the Oidium pathogen occurs on the young rubber leaves that grow after defoliation, which coincides with dry weather. Therefore, both decreased rainfall and excessive rainfall would suppress Oidium infection. If climate change causes a rainfall reduction in the major rubber-growing districts, a decrease in Oidium leaf fall could be expected in rubber. Similarly, decreased rainfall, mist and atmospheric humidity in the upper elevations of the tea-growing regions of Sri Lanka, where blister blight is prevalent at present, could cause a reduction in the incidence of blister blight. However, increasing temperatures could cause increases in the above fungal diseases, especially if the warm periods coincide with periods of leaf wetness, mist and high atmospheric humidity. Research on the impacts of climate change on pests and diseases of agricultural crops is relatively limited ${ }^{66}$ in comparison to research on impacts of climate change on physiological processes related to growth and yield formation. Intensified research is needed to understand how the complex hostpathogen interactions would be influenced by climate change. However, during the last decade, some significant advances have been made to be able to synthesize the effects of climate change on pathogen infection rates at 
the individual plant level ${ }^{70-72}$. Much work has been done at the genomic level to discriminate and understand the changes in gene expression due to different biotic and abiotic stressors. Despite the substantial challenges and significant uncertainties that are involved, predictive models are being developed to forecast the impacts of climate change on the occurrence of plant diseases ${ }^{73-75}$.

An extensive body of research literature on the impacts of climate change on important agricultural crops has been built based on research conducted, largely in developed countries in the temperate climates ${ }^{21,51}$. While some of these research findings could be extrapolated to the tropical climate of Sri Lanka, a comprehensive and extensive research effort within Sri Lanka is needed to obtain in situ quantitative assessments of climate change impacts on Sri Lankan crops under climatic conditions prevailing in Sri Lanka. These impact assessments could be through actual experiments, the results of which can be used to develop and calibrate simulation models to make predictions of impacts under future climate change scenarios ${ }^{76-78}$. Assessing the regional and local variations of climate change impacts, which result from interactions between agro-climatic and socioeconomic conditions specific to a given region or location, presents a considerable challenge ${ }^{79-82}$.

An important outcome of accurate prediction of future impacts would be identification of vulnerable crops, regions and farming communities ${ }^{53,83}$. Vulnerability of farming communities will depend not only on the climatic factors but also on a complex set of socio-cultural and economic factors, which will have to be investigated in the light of climate change. Very often, smallholder subsistence farming communities, who form a significant portion of the farmers in the tropics including Sri Lanka, have a lower capacity for adapting to climate change and therefore show greater vulnerability ${ }^{84}$. Accurate quantification of climate change impacts and vulnerability could also lead to mapping of vulnerable areas and communities. Another important aspect of climate change impact assessment is the economic valuation of the impacts and vulnerabilities ${ }^{85-87}$. Such economic assessments of climate change impacts, especially the damages to crops and farmer livelihoods, could catalyze the thinking of politicians and administrators on the need for a policy framework for climate change adaptation. Although there are increasingly frequent reports in Sri Lanka of crop losses due to climate-related causes and especially due to extreme climate events such as droughts and floods, a complete quantitative compilation of these losses has not been carried out by any relevant governmental or non-governmental body. Therefore, the impact of climate change-related events on the overall
GDP of Sri Lanka has not been quantified. However, the following assessments on some key areas of Sri Lankan agriculture and the economy illustrate the threat posed by climate change and the need to formulate adaptation strategies.

Sri Lankan tea production in the first seven months of 2009 has shown a $21 \%$ reduction, amounting to 42.56 million $\mathrm{kg}$ of made tea in comparison to the corresponding period in $2008^{88}$. Although the reduced supply causes the tea prices to increase, the above reduction in overall production cost the country a considerable amount of valuable foreign exchange in the form of lost export earnings. Out of several factors which could have contributed to the above loss, the drought during the months of June and July due to a weak southwest monsoon in the Indian sub-continent was probably a significant contributory factor ${ }^{89-91}$. This is supported by the fact that the loss of tea crop has been higher in the warmer lower and mid elevations (i.e. $25 \%$ and $26 \%$ respectively) than in the cooler higher elevations (i.e. $14 \%)$.

Extremely low rainfall during the period from September to December in 2003 and in January 2004 caused a severe drought in the districts of Hambantota, Anuradhapura, Moneragla, Badulla, Kurunegala, Puttalam and Mannar in early 2004 ${ }^{92}$. The period of extremely low rainfall coincided with the major rainfall and crop cultivation season (locally known as the Maha season) in the dry zone of Sri Lanka. Therefore, 52,652 ha of crops were damaged affecting 231,076 families. The drought relief allocations cost 477 million Sri Lankan Rupees (SLR).

Although floods are a common occurrence in Sri Lanka during the monsoon seasons, there have been extreme floods from time-to-time causing substantial crop damage and displacement of large numbers of people, mainly farmers. For example, the severe floods that occurred in Ratnapura, Sri Lanka (6.6833 ${ }^{\circ} \mathrm{N}$, $80.4000^{\circ} \mathrm{E}, 33 \mathrm{~m}$ above $\mathrm{msl}$ ) in May 2003 caused damage to 3014 ha of paddy lands and 256 ha of lands grown with other field crops $^{93}$. These included 399 minor irrigation schemes covering an area of 3053 ha. The total economic loss caused by this flood was 7 billion SLR and the total reconstruction expenditure amounted to 2 billion SLR. In December 2004, floods caused by the extremely high north-east monsoonal rain displaced around 120,000 families in the eastern coast of Sri Lanka and inundated over 400,000 ha of agricultural land ${ }^{94}$.

According to the National Disaster Relief Management Centre, a total of 567,630 people were 
affected by climate-related hazards in $2008^{95}$. Out of these $86 \%$ were affected by floods, followed by $10 \%$ due to drought and $2.7 \%$ due to landslides. The total cost of relief, rehabilitation and reconstruction was 225 million SLR, with floods $(71 \%)$, droughts $(9 \%)$ and landslides $(10 \%)$ requiring the highest expenditure.

The Stern Review ${ }^{87}$ provides comprehensive globalscale economic assessments on the impacts of climate change and predicts, in a business-as-usual scenario, an average loss of $5-10 \%$ in the global GDP by the end of this century with a predicted warming of $5-6^{\circ} \mathrm{C}$. The poorer countries are predicted to incur GDP losses in excess of $10 \%$.

Substantial and sustained long-term investment of research funds will be needed to generate valid and useful information on climate change impacts and vulnerability on different sub-sectors of agriculture. These funds will have to be channelled to existing research institutions and universities and to new institutions and centres that may be established. The personnel involved will be research scientists from both research institutes and universities. There should also be a substantial investment in human resource development to produce a critical mass of scientists trained on climate change and its impact assessment.

\section{Identification and formulation of responses to adapt to climate change}

Quantification and prediction of probable changes in climate and their impacts should form the basis for identification and formulation of adaptation measures, which can be both shorter-and longer-term. Accurate prediction of key changes in climate such as increasing frequency of drought, periods of higher and lower temperatures and vulnerable crops may enable farmers to select cultivars which are better adapted to the changed climate and adjust their planting times to avoid periods of stress. They may even be convinced to make changes in the choice of crops that they cultivate.

The long-term solution to adapt to climate change would be to develop new crop varieties which perform better under the climatic conditions that are predicted for the future. For example, rice varieties which are highly responsive to higher atmospheric $\mathrm{CO}_{2}$ concentrations have been identified from the Sri Lankan rice germplasm ${ }^{96}$. Likewise, research is under way in Sri Lanka to identify rice varieties which are more productive under higher temperatures and under conditions of lower water availability ${ }^{97}$. Salt tolerant rice varieties such as AT354 have already been bred and further research is in progress to identify additional salt tolerant varieties from the Sri Lankan rice germplasm ${ }^{98,99}$.

Incorporation of drought tolerance is a key breeding objective in varietal improvement programmes of a range of crops including perennials such as tea and coconut and in annuals such as pulses and coarsegrained cereals. Significant advances have been made in breeding flood-tolerant rice at the IRRI with a new group of rice varieties, which are able to withstand two weeks of complete submergence, being at an advanced stage of field testing ${ }^{81,100}$. Similarly, aerobic rice, another group of rice varieties, which have a substantially lower water requirement, are being tested at IRRI and in many tropical rice-growing countries including Sri Lanka ${ }^{97,101}$. Considerable advances have been made to understand the mechanisms of drought tolerance in rice ${ }^{102}$, which could be the basis of breeding drought tolerant rice. While the breeding of resistant varieties, which is a slow process taking 5-10 years on the average from initiation to release of a new variety, is in progress, modified crop management practices could help the existing varieties to adapt to climate change. For example, alternative water management practices, which enable growing of rice under lowland conditions, with a lower water input than is currently used without a significant yield reduction have been demonstrated ${ }^{97,103-106}$. A previous study ${ }^{99}$ has shown that high rice yields can be obtained by a combination of agronomic measures to reduce field salinity (i.e. improved drainage, application of organic manure, rice straw and burnt paddy husk and transplanting instead of broadcasting) and newly-developed salt-tolerant breeding lines.

While this policy initiative requires a substantial input from research scientists, especially plant breeders and crop physiologists, a close linkage between research scientists and extension workers, who take the research findings to the farmers, is essential. A substantial investment is also needed to create awareness among the farming community on the impacts of climate change and the needed adaptation measures.

Creating and strengthening the institutional framework and infrastructure to implement and monitor adaptation measures to climate change

Implementation of formulated adaptation strategies needs a well-coordinated institutional network involving both governmental and non-governmental agencies along with farmer community groups and organizations. The work of this institutional network includes formulation of action plans for implementation of adaptation measures recommended by scientists, facilitating 
and monitoring the adoption of adaptation measures, solving problems that occur during implementation and providing a feedback to the scientists on success or failure of recommended adaptation measures. The existing research and extension arms of the National Agricultural Research System (NARS) and the various governmental institutions mandated with contributing to national agricultural development and food security should be strengthened to undertake the above tasks effectively. With the exceptions of rice ${ }^{44-46,69,96-99,107}$, tea $^{47,48,53,83}$ and coconut ${ }^{108,109}$, the awareness and priority given to research on climate change and its impacts on different agricultural crops in Sri Lanka has been minimal. Even in the above three crops, a considerable amount of research and extension work needs to be done to minimize the vulnerability and impacts of climate change on them and their growers. Therefore, a substantial investment in physical infrastructure development and human resource development is required in all croprelated research institutes within the NARS. Within this institutional framework, mechanisms have to be in place to ensure inter-institutional collaboration and coordination. Existing organizations such as the National Science Foundation of Sri Lanka (NSF) or the Sri Lanka Council for Agricultural Research Policy (CARP) could play this role. However, the present capacity of these organizations to carry out effective coordination and monitoring of inter-institutional programmes is constrained by several factors such as the shortage of trained and experienced staff and severe limitations in funding. Furthermore, these two institutions have their existing work programmes, which are being carried out with extreme difficulty due to the limitations of the above-mentioned resources.Therefore, it is doubtful whether the NSF or the CARP could provide effective inter-institutional co-ordination and monitoring of research and development programmes aimed at bringing about climate change adaptation in agricultural crop production. A new institution with adequate resources, and perhaps the authority to enforce inter-institutional collaboration, would have greater probability of playing this role effectively.

Another key component of an institutional framework is to establish incentive schemes for adoption of adaptation measures and compensation and insurance schemes against crop losses due to events related to climate change such as extreme climatic events.

Within the available institutional framework, a formulated policy for adaptation of agricultural crop production to climate change should also have a clear strategy and a roadmap for implementation of adaptation measures agreed upon by the different stakeholders.
A previous study ${ }^{110}$ suggests that implementation of adaptation measures to short-term climate variability and extreme climatic events should precede measures of adapting and reducing the vulnerability to longerterm climate change. This would be a sound strategy in developed countries with strong institutional networks and more motivated politicians and administrators. In developing countries with weaker institutional networks and short-sighted politicians and administrators, such a strategy could forever postpone key adaptation measures to long-term climate change. The above study ${ }^{110}$ emphasizes, quite correctly, that the process of stakeholder implementation of adaptation strategies is as important as the adaptation strategy itself. Furthermore, climate change adaptation strategies should be linked to a prevailing overall developmental policy framework with the involvement of all levels of the society from the administrators to the grass root levels.

\section{Concluding remarks}

A well-formulated policy should provide an overall vision, a set of broad objectives to be achieved and a set of guidelines, along which the action plans could be drawn. What has been outlined above is a broad framework of a policy for successful adaptation of the Sri Lankan agriculture sector to climate change. However, having a well-formulated policy would not achieve its objectives unless there is a commitment from all its stakeholders to its implementation. A pre-requisite for successful implementation is the allocation of sufficient financial resources and building-up of a critical mass of human resource pool, the institutional framework and the infra-structure. It has to be emphasized that the basis for formulation of successful adaptation measures to climate change for Sri Lankan agriculture is a comprehensive and sustained, long-term research effort. The required support for such a research effort, from both government authorities and international donor agencies, has been far from adequate in Sri Lanka. Therefore, in an environment of limited resource allocation for long-term climate change research, it is essential that research priorities are identified in terms of regions, crops and farming communities that are at the greatest risk from climate change so that resources for adaptation can be allocated at the earliest ${ }^{80,81,111}$.

\section{Acknowledgement}

The author wishes to thank the organizers of the symposium on 'Promoting Knowledge Transfer to Strengthening Disaster Risk Reduction \& Climate Change Adaptation' held on the $7^{\text {th }} \& 8^{\text {th }}$ July 2009 in Colombo for providing the motivation to write this 
article. Helpful comments from a referee and Dr. M.C.M. Iqbal, Senior Research Fellow, Institute of Fundamental Studies, Kandy to revise the manuscript are gratefully acknowledged.

\section{References}

1. Abeyratne F. (2008). Global food crisis: causes and effects at global level. Economic Review (Sri Lanka) 34(7\&8): 2-5.

2. Anonymous (2007). Annual Report. Central Bank of Sri Lanka, Colombo.

3. Gunasena H.P.M. (2008). Strategies for increasing food production in Sri Lanka: some suggestions for government's food production drive. Economic Review (Sri Lanka) 34(7\&8): 28-31.

4. IPCC (2001). Climate Change 2001: Synthesis Report. A Contribution of Working Groups I, II, and III to the Third Assessment Report of the Intergovernmental Panel on Climate Change (Eds. R.T. Watson \& the Core Writing Team). p. 398. Cambridge University Press, Cambridge, UK and New York.

5. Easterling D.R., Meehl G.A., Parmesan C., Changnon S.A., Karl T.R. \& Mearns L.O. (2000). Climate extremes: observations, modelling, and impacts. Science 289: 20682074.

6. Tompkins H. (2002). Climate change and extreme weather events: is there a connection? Cicerone 3:1-5.

7. De Costa W.A.J.M. (2008). Climate change in Sri Lanka: myth or reality? evidence from long-term meteorological data. Journal of the National Science Foundation of Sri Lanka 36 (Special Issue): 63-88.

8. Domroes M. (1996). Rainfall variability over Sri Lanka, In: Climate Variability and Agriculture. (Eds. Y.P. Abrol, S. Gadgil S. \& G.B. Pant). pp. 163-179. Narosa Publishing House, New Delhi, India.

9. Chandrapala L. (1996). Long term trends of rainfall and temperature in Sri Lanka. In: Climate Variability and Agriculture. (Eds. Y.P. Abrol, S. Gadgil S. \& G.B. Pant). pp. 153-162. Narosa Publishing House, New Delhi, India.

10. Malmgren B.A., Hulugalla R., Hayashi Y. \& Mikami T. (2003). Precipitation trends in Sri Lanka since the 1870 s and relationships to El Niño-Southern Oscillation. International Journal of Climatology 23: 1235-1252.

11. Ranatunge E., Malmgren B.A., Hayashi Y., Mikami T., Morishima W., Yokozawa M. \& Nishimori M. (2003). Changes in the SouthWest Monsoon mean daily rainfall intensity in Sri Lanka: relationship to the El-Niño Southern Oscillation Palaeogeography, Palaeoclimatology, Palaeoecology 197: 1-14.

12. Fernando T.K. (2000). Impact of climate change on paddy production in Sri Lanka. Global Environmental Research 2: 169-176.

13. Nakagawa H. \& Horie T. (2000). Rice responses to elevated $\mathrm{CO}_{2}$ and temperature. Global Environmental Research 2: 101-113.

14. Wijeratne M.A. \& Fordham R. (1996). Effect of environmental factors on growth and yield of tea (Camellia sinensis L.) in the low country wet zone of Sri Lanka. Sri Lankan Journal of Tea Science 46: 21-34.

15. Bouman B.A.M. (2001). Water-efficient management strategies in rice production. International Rice Research Newsletter 26(2): 17-22.

16. Horie T., Baker J.T., Nakagawa H., Matsui T. \& Kim H.Y. (2000). Crop ecosystem responses to climatic change: Rice. In: Climate Change and Global Crop Productivity. (Eds. K.R. Reddy \& H.F. Hodges) pp. 81-106. CAB International, Wallingford, UK.

17. Weerakoon W.M.W., Maruyama A. \& Ohba K. (2008). Impact of humidity on temperature-induced grain sterility in rice (Oryza sativa L). Journal of Agronomy and Crop Science 194: 135-140.

18. Watson M. (1986). Soil and climatic requirements. In: Handbook on Tea. (Eds. P. Sivapalan, S. Kulasegaram \& A. Kathiravetpillai) pp. 3-5. Tea Research Institute of Sri Lanka, Talawakelle.

19. De Costa W.A.J.M., Mohotti A.J. \& Wijeratne M.A. (2007). Ecophysiology of tea. Brazilian Journal of Plant Physiology 19: 299-332.

20. Reddy K.R. \& Hodges H.F. (2000). Climate Change and Global Crop Productivity. p. 472. CAB Internationl, Wallingford, UK.

21. Porter J.R. \& Semenov M.A. (2005). Crop responses to climatic variation. Philosophical Transactions of the Royal Society B: Biological Sciences 360: 2021-2035.

22. Mitchell J.F.B., Johns T.C., Ingram W. J. \& Lowe J.A. (2000). The effect of stabilising atmospheric carbon dioxide concentrations on global and regional climate change. Geophysical Research Letters 27: 2977-2980.

23. Dai A., Wigley T.M.L., Meehl G.A. \& Washington W.M. (2001). Effects of stabilizing atmospheric $\mathrm{CO}_{2}$ on global climate in the next two centuries. Geophysical Research Letters 28: 4511-4514.

24. Pielke R.A. (1998). Rethinking the role of adaptation in climate policy. Global Environmental Change 8: 159170.

25. Munasinghe M. \& Swart R. (2005). Primer on Climate Change and Sustainable Development: Facts, Policy Analysis and Applications. Cambridge University Press, Cambridge, UK.

26. IPCC (2007a). Climate Change 2007: Synthesis Report. Contribution of Working Groups I, II and III to the Fourth Assessment Report of the Intergovernmental Panel on Climate Change (Eds. Core Writing Team, R.K. Pachauri \& A. Reisinger). p. 104. IPCC, Geneva, Switzerland,

27. IPCC (2007b). Climate Change 2007: The Physical Science Basis. Contribution of Working Group I to the Fourth Assessment Report of the Intergovernmental Panel on Climate Change (Eds. S. Solomon, D. Qin, M. Manning, Z. Chen, M. Marquis, K.B. Averyt, M. Tignor \& H.L. Miller). p. 996 Cambridge University Press, Cambridge, UK and New York.

28. Murphy J.M., Sexton D.M.H., Barnett D.N., Jones G.S., Webb M.J., Collins M. \& Stainforth D.A. (2004). Quantification of modeling uncertainties in a large ensemble of climate change simulations. Nature 430: 768-772. 
29. Giorgi F. \& Francisco R. (2000). Evaluating uncertainties in the prediction of regional climate change. Geophysical Research Letters 27: 1295-1298.

30. Domroes M. (1974). The Agroclimate of Ceylon. Franz Steiner Verlag: Wiesbaden.

31. Panabokke C.R. (1996). Soils and Agro-ecological Environments of Sri Lanka. Natural Resources, Energy and Science Authority of Sri Lanka, Maithland Place, Colombo.

32. Punyawardena B.V.R., Bandara T.M.J., Munasinghe M.A.K., Banda N.J. \& Pushpakumara S.M.V. (2003). Agro-ecological regions of Sri Lanka. Natural Resources Management Centre, Department of Agriculture, Peradeniya.

33. Chithranayana R.D. \& Punyawardena B.V.R. (2008). Identification of drought prone agro-ecological regions in Sri Lanka. Journal of the National Science Foundation of Sri Lanka 36: 117-124.

34. Sun S. \& Hansen J.E. (2003). Climate simulations for 1951-2050 with a coupled atmosphere-ocean model. Journal of Climate 16: 2807-2826.

35. Meehl G.A., Karl T., Easterling D.R., Changnon S., Pielke Jr. R., Changnon D., Evans J., Groisman P.Y., Knutson T.R., Kunkel K.E., Mearns L.O., Parmesan C., Pulwarty R., Root T., Sylves R.T., Whetton P. \& Zwiersl F. (2000). An introduction to trends in extreme weather and climate events: observations, socioeconomic impacts, terrestrial ecological impacts, and model projections. Bulletin of the American Meteorological Society 81: 413-416.

36. Palmer T.N. \& Raisanen J. (2002). Quantifying the risk of extreme seasonal precipitation events in a changing climate. Nature 415: 512-517.

37. Thorpe A.J. (2005). Climate Change Prediction: A Challenging Scientific Problem. p. 16. Institute of Physics, London, UK.

38. Stainforth D.A., Aina T., Christensen C., Collins M., Faull N., Frame D.J., Kettleborough J.A., Knight S., Martin A., Murphy J.M., Piani C., Sexton D., Smith L.A., Spicer R.A., Thorpe A.J. \& Allen M.R. (2005). Uncertainty in predictions of the climate response to rising levels of greenhouse gases. Nature 433: 403-406.

39. Bader D.C., Covey C., Gutowski W.J., Held I.M., Kunkel K.E., Miller R.L., Tokmakian R.T. \& Zang M.H. (2008). Climate Models: An Assessment of Strengths and Limitations. A Report by the U.S. Climate Change Science Programme. U.S. Department of Energy, Washington, DC.

40. Reilly J., Stone P.H., Forest C.E., Webster M.D., Jacoby H.D. \& Prinn R.G. (2001). Uncertainty and climate change assessments. Science 293: 430-433.

41. Webster M., Forest C., Reilly J., Babiker M., Kicklighter D., Mayer M., Prinn R., Sarofim M., Sokolov A., Stone P. $\&$ Wang C. (2004). Uncertainty analysis of climate change and policy response. Climate Change 61: 295-320.

42. Allen M.R. \& Stainforth D.A. (2002). Towards objective probabilistic climate forecasting. Nature 419: 228.

43. Stott P.A. \& Kettleborough J.A. (2002). Origins and estimates of uncertainty in predictions of twenty-first century temperature rise. Nature 416: 723-726.
44. De Costa W.A.J.M., Weerakoon W.M.W., Herath H.M.L.K. \& Abeywardena R.M.I. (2003). Response of growth and yield of rice (Oryza sativa) to elevated atmospheric carbon dioxide in the sub-humid zone of Sri Lanka. Journal of Agronomy and Crop Science 189: 83-95.

45. WeerakoonW.M.W.,DeCostaW.A.J.M.\&Abeysiriwardena D.S. de Z. (2005). Physiological responses of indica rice varieties to increased atmospheric $\mathrm{CO}_{2}$ and temperature. Journal of Agricultural Meteorology 60: 601-604.

46. De Costa W.A.J.M. \& Piyasena H.D.A.S. (2006). Influence of temperature on growth, phenology and yield of different rice (Oryza sativa L.) varieties in Sri Lanka. Sri Lankan Journal of Agricultural Sciences 43: 1-21.

47. Wijeratne M.A., Ratnasiri J. \& Premathunga E.W.T.P. (2007). Effect of $\mathrm{CO}_{2}$ fertilization on growth and yield of mature tea in the low country wet zone of Sri Lanka. Journal of Plantation Crops 35: 56-58.

48. Wijeratne M.A., Anandacoomaraswamy A., Amarathunga M.K.S.L.D., Ratnasiri J., Basnayake B.R.S.B. \& Kalra N. (2007). Assessment of impact of climate change on productivity of tea (Camellia sinensis L.) plantations in Sri Lanka. Journal of the National Science Foundation of Sri Lanka 35: 119-26.

49. Kimball B.A. (1983). Carbon dioxide and agricultural yield: an assemblage and analysis of 430 prior observations. Agronomy Journal 75: 779-786.

50. Kimball B.A., Kobayashi K. \& Bindi M. (2002). Responses of agricultural crops to free-air $\mathrm{CO}_{2}$ enrichment. Advances in Agronomy 77: 293-368.

51. Tubiello F.N., Soussana J-F. \& Howden S.M. (2007). Crop and pasture response to climate change. Proceedings of the National Academy of Sciences USA 104: 19686-19690.

52. Gifford R.M. (2004). The $\mathrm{CO}_{2}$ fertilizing effect - does it occur in the real world? New Phytologist 163: 221-225.

53. Ratnasiri J., Anandacoomaraswamy A., Wijeratne M.A., Basnayake S., Jayakody A. \& Amaratunga L. (2008). Vulnerability of Sri Lankan tea plantations to climate change. In: Climate Change and Vulnerability. (Eds. N. Leary, C. Conde, J. Kulkarni, A. Nyong \& J. Pulhin), pp. 351-372. Earthscan/International START Secretariat, UK/ USA.

54. IPCC (2007). Climate Change 2007: Impacts, Adaptation and Vulnerability. Contribution of Working Group II to the Fourth Assessment Report of the Intergovernmental Panel on Climate Change. (Eds. M.L. Parry, O.F. Canziani, J.P. Palutikof, van der P.J. Linden \& C.E. Hanson) p. 976. Cambridge University Press, Cambridge, UK,

55. Porter J.R. (2005). Rising temperatures are likely to reduce crop yields. Nature 436: 174.

56. Howden S.M., Soussana J-F., Tubiello F.N., Chhetri N., Dunlop M. \& Meinke H. (2007). Adapting agriculture to climate change. Proceedings of the National Academy of Sciences USA 104: 19691-19696.

57. Peng S., Huang J., Sheehy J.E., Laza R.C., Visperas R.M., Zhong X., Centeno G.S., Khush G.S. \& Cassman K.G. (2004). Rice yields decline with higher night temperature from global warming. Proceedings of the National Academy of Sciences USA 104: 9971-9975. 
58. Cheng W., Sakai H., Yagi K. \& Hasegawa T. (2009). Interactions of elevated $\mathrm{CO}_{2}$ and night temperature on rice growth and yield. Agricultural and Forest Meteorology 149: 51-58.

59. Wheeler T.R., Crauford P. Q., Ellis R.H., Porter J.R. \& Vara Prasad P.V. (2000). Temperature variability and the yield of annual crops. Agriculture, Ecosystems \& Environment 82: 159-167.

60. Vara Prasad P.V., Craufurd P.Q., Summerfield R.J. \& Wheeler T.R. (2000). Effects of short-episodes of heat stress on flower production and fruit-set of groundnut (Arachis hypogaea L.). Journal of Experimental Botany 51: 777-784.

61. Long S.P., Ainsworth E.A., Leakey A.D.B. \& Morgan P.B. (2005). Global food insecurity. Treatment of major food crops with elevated carbon dioxide or ozone under largescale fully open-air conditions suggests recent models may have overestimated future yields. Philosophical Transactions of the Royal Society: Biological Science 360: 2011-2020.

62. Long S.P., Ainsworth E.A., Leaky A.D.B., Nösberger J. \& Ort D.R. (2006). Food for thought: lower-than-expected crop yield stimulation with rising $\mathrm{CO}_{2}$ concentrations. Science 312: 1918-1921.

63. Leakey A.D.B., Ainsworth E.A., Bernacchi C.J., Rogers A., Long S.P. \& Ort D.R. (2009). Elevated $\mathrm{CO}_{2}$ effects on plant carbon, nitrogen, and water relations: six important lessons from FACE. Journal of Experimental Botany 60: 2859-2876.

64. Tubiello F.N., Amthor J.A., Boote K., Donatelli M., Easterling W., Fischer G., Gifford R., Howden M., Reilly J. \& Rosenzweig C. (2006). Crop response to elevated $\mathrm{CO}_{2}$ and world food supply: A comment on "Food for Thought..." by Long et al., Science 312:1918-1921, European Journal of Agronomy 26: 215-222.

65. Anderson P.K., Cunningham A.A., Patel N.G., Morales F.J., Epstein P.R. \& Daszak P. (2004). Emerging infections diseases of plants: pathogen pollution, climate change and agrotechnology drivers. Trends in Ecology \& Evolution 19: $535-544$.

66. Coakley S.M., Scherm H. \& Chakraborty S. (1999). Climate change and plant disease management. Annual Review of Phytopathology 37: 399-426.

67. Chakraborty S. \& Datta S. (2003). How will plant pathogens adapt to host plant resistance at elevated $\mathrm{CO}_{2}$ under a changing climate? New Phytologist 159: 733742 .

68. Mohotti K.M. (2009). Marked shift in damage caused by parasitic nematode species in tea with long-term climate change. In: Proceedings of the First National Conference on Climate Change \& Its Impacts on Agriculture, Forestry and Water. pp. 30-31, (Eds. W.A.J.M. De Costa, S.P. Nissanka, A.J. Mohotti \& W.M.W. Weerakoon). 10-11 Sept. 2009, Kandy.

69. De Costa D.M., Kishimoto N. \& De Costa W.A.J.M. (2009). Effects of elevated $\mathrm{CO}_{2}$ on culturable epiphytic microbial populations on the phyllosphere of rice. Sri Lanka Journal of Agricultural Science (In Press).

70. Scherm H. \& Coakley S.M. (2003). Plant pathogens in a changing world. Australasian Plant Pathology 32:157-165.

71. Garrett K.A., Dendy S.P., Frank E.E., Rouse M.N. \& Travers S.E. (2006). Climate change effects on plant disease: genomes to ecosystems. Annual Review of Phytopathology 44: 489-509.

72. Sutherst R.W., Baker R.H.A., Coakley S.M., Harrington R., Kriticos D.J. \& Scherm H. (2007). Pests under global change - meeting your future landlords? In: Terrestrial Ecosystems in Changing World. (Eds. J.G. Canadell, D.E. Pataki \& L.F. Pitelka), pp. 211-226. Springer, Berlin, Heidelberg, Germany.

73. Scherm H. (2000). Simulating uncertainty in climate-pest models with fuzzy numbers. Environmental Pollution 108: $373-379$.

74. Scherm H. (2004). Climate change: can we predict the impacts on plant pathology and pest management? Canadian Journal of Plant Pathology 26: 267-273.

75. Seem R.C. (2004). Forecasting plant disease in a changing climate: a question of scale. Canadian Journal of Plant Pathology 26: 274-83.

76. Matthews R.B., Kropff M.J., Bachelet D. \& van Laar L.H. (1995). Modelling the Impact of Climate Change on Rice Production in Asia. p.289. International Rice Research Institute/CAB International.

77. Seo S.N.O.N., Mendelsohn R. \& Munasinghe M. (2005). Climate change and agriculture in Sri Lanka: a Ricardian valuation. Environment and Development Economics 10: 581-596.

78. Challinor A.J., Ewert F., Arnold S., Simelton E. \& Fraser E. (2009). Crops and climate change: progress, trends, and challenges in simulating impacts and informing adaptation. Journal of Experimental Botany 60: 2775-2789.

79. Rosenzweig C. \& Parry M.L. (1994). Potential impact of climate change on world food supply. Nature 367: 133138.

80. Fischer G., Shah M., Tubiello F.N. \& van Velthuizen H. (2005). Socio-economic and climate change impacts on agriculture: an integrated assessment. 1990-2080 Philosophical Transactions of the Royal Society B: Biological Sciences 360: 2067-2083.

81. Parry M., Rosenzweig C. \& Livermore M. (2005). Climate change, global food supply and risk of hunger. Philosophical Transactions of the Royal Society B: Biological Sciences 360: 2125-2138.

82. Schmidhuber J. \& Tubiello F.N. (2007). Global food security under climate change. Proceedings of the National Academy of Sciences USA 104: 19703-19708.

83. Wijeratne M.A. (1996). Vulnerability of Sri Lankan tea plantations to global climate change. Water, Air and Soil Pollution 92:87-94.

84. Morton J.F. (2007). The impact of climate change on smallholder and subsistence agriculture. Proceedings of the National Academy of Sciences USA 104: 1968019685.

85. Munasinghe M., Meier P., Hoel M., Wong S. \& Aaheim A. (1996). Applicability of techniques of cost-benefit analysis to climate change. In: Climate Change 1995: Chapter 5: Economic and Social Dimensions. (Eds. J.P. Bruce, H. 
Lee \& E.H. Haites), Inter governmental Panel on Climate Change (IPCC), Geneva, Cambridge University Press, Cambridge, UK.

86. Munasinghe M. (1998). Climate change decision-making: science, policy and economics. International Journal of Environmental Pollution 10: 188-239.

87. Stern N. (2007). The Economics of Climate Change: The Stern Review. Cambridge University Press, Cambridge, $\mathrm{UK}$.

88. http://www.lankabusinessonline.com/fullstory. php? nid $=18877$ 6268. Accessed on 20 October 2009.

89. http://www.sciencedaily.com/releases/2009/02/09022711 2307.htm. Accessed on 20 October 2009.

90. Asfaq M., Shi Y., Tung W., Trapp R.J., Gao X., Pal J.S. \& Diffenbaugh N.S. (2009). Suppression of South Asian summer monsoon precipitation in the $21^{\text {st }}$ century. Geophysical Research Letters 36: L01704 DOI:10.1029/2008GL036500.

91. http://www.globalenvision.org/2009/08/02/late-weakand-erratic-monsoon-india-could-hurt-economicrebound. Accessed on 20 October 2009.

92. http://www.ndmc.gov.lk/. Accessed on 20 October 2009.

93. Anonymous (2004). Damages from Floods and Landslides in Ratnapura District in 2003. District Secretariat, Ratnapura.

94. http://visibleearth.nasa.gov/view_rec.php?id $=19765$. Accessed on 20 October 2009.

95. http://www.ndmc.gov.lk/. Accessed on 20 October 2009.

96. De Costa W.A.J.M., Weerakoon W.M.W., Chinthaka K.G.R., Herath H.M.L.K. \& Abeywardena R.M.I. (2007). Genotypic variation in the response of rice (Oryza sativa L.) to increased atmospheric carbon dioxide and its physiological basis. Journal of Agronomy and Crop Science 193: 117-130.

97. Jayawardhana E.M.S., De Costa W.A.J.M. \& Weerakoon W.M.W. (2009). Screening of rice varieties for better performance under water-saving irrigation regimes. In: Proceedings of the Final Year Student Research Sessions, $30^{\text {th }}$ April 2009, Department of Crop Science, Faculty of Agriculture, University of Peradeniya. (Ed. R.M. Fonseka). pp. 5-7. University of Peradeniya, Peradeniya.

98. Dharmasena A.W.T.D. \& De Costa W.A.J.M. (2009). Screening of a selected set of rice varieties for salinity tolerance in two phases of salt stress development. In: Proceedings of the Final Year Student Research Sessions, $30^{\text {th }}$ April 2009, Department of Crop Science, Faculty of Agriculture, University of Peradeniya. (Ed. R.M. Fonseka) pp. 11-14. University of Peradeniya, Peradeniya.

99. Gamage J., Abeysinghe S., Abeygunawardana H. \& Sirisena D. (2009). Climate variability and rural livelihoods: mitigating the impact of soil salinity on paddy cultivation in Sri Lanka. In: Proceedings of the National Symposium on Promoting Knowledge Transfer to Strengthen Disaster Risk Reduction \& Climate Change Adaptation, 7-8 July 2009, Colombo, p. 5. Disaster Management Centre of the Ministry of Disaster Management \& Human Rights, Colombo 7.
100. Barclay A. (2009). Scuba rice: stemming the tide in floodprone South Asia. Rice Today 8(2): 26-31.

101. Bouman B.A.M., Peng S., Castañeda A.R. \& Visperas R.M. (2005). Yield and water use of irrigated tropical aerobic rice systems. Agricultural Water Management 74: $87-105$.

102. Serraj R., Bennett J. \& Hardy B. (2008). Drought frontiers in rice: crop improvement for increased rainfed production. p. 400. World Scientific Publishing, Singapore and International Rice Research Institute, Los Banos, Philipines.

103. Guerra L.C., Bhuiyan S.I., Tuong T.P. \& Barker R. (1998). Producing more rice with less water from irrigated systems. SWIM Paper 5. p. 24. International Water Management Institute/International Rice Research Institute, Colombo.

104. Bouman B.A.M. \& Tuong T.P. (2001). Field water management to save water and increase its productivity in irrigated lowland rice. Agricultural Water Management 49: $11-30$.

105. Belder P., Bouman B.A.M., Cabangon R., Lu G., Quilang E.J.P., Li Y.H., Spiertz J.H.J. \& Tuong T.P. (2004). Effect of water-saving irrigation on rice yield and water use in typical lowland conditions in Asia. Agricultural Water Management 65: 193-210.

106. Belder P., Bauman B.A.M. \& Spiertz J.H.J. (2007). Exploring options for water savings in lowland rice using a modelling approach. Agricultural Systems 92: 91-114.

107. Weerakoon W.M.W. \& De Costa W.A.J.M. (2009). Impacts of climate change on rice production in Sri Lanka. In: Proceedings of the First National Conference on Climate Change \& Its Impacts on Agriculture, Forestry and Water. pp. 6-7, (Eds. W.A.J.M. De Costa, S.P. Nissanka, A.J. Mohotti \& W.M.W. Weerakoon). 10-11 Sept. 2009, Kandy.

108. Ranasinghe C.S. (2009). Impacts of climate change on productivity of coconut plantations - overview of past and present research. In: Proceedings of the First National Conference on Climate Change \& Its Impacts on Agriculture, Forestry and Water. p. 26, (Eds. W.A.J.M. De Costa, S.P. Nissanka, A.J. Mohotti \& W.M.W. Weerakoon). 10-11 Sept. 2009, Kandy.

109. Nainanayake A.D. (2009). Screening of coconut germplasm for drought tolerance - an approach for adaptation to climate change. In: Proceedings of the First National Conference on Climate Change \& Its Impacts on Agriculture, Forestry and Water. p. 27, (Eds. W.A.J.M. De Costa, S.P. Nissanka, A.J. Mohotti \& W.M.W. Weerakoon). 10-11 Sept. 2009, Kandy.

110. Lim B. \& Spanger-Siegfried E. (2004). Adaptation Policy Frameworks for Climate Change: Developing Strategies,Policies and Measures. UNDP/Cambridge University Press, Cambridge, UK.

111. Lobell D.B., Burke M.B., Tebaldi C., Mastrandrea M.D., Falcon W.P. \& Naylor R.L. (2008). Prioritizing climate change adaptation needs for food security in 2030. Science 319: $607-610$ 